\title{
Effect of $\beta$-mannanase, Lysolecithin and probiotic on some reproductive performance and hormone profile in female quail
}

\author{
H.M. Hameed ${ }^{1 *}$, F.K. Tawfeek ${ }^{1}$ and S.Y. Adul-Rhaman ${ }^{2}$ \\ ${ }^{1}$ Department of Physiology, Biochemistry and Pharmacology, College of Veterinary Medicine, ${ }^{2}$ Department of Animal \\ Resource, College of Agriculture and Forestry, University of Mosul, Mosul, Iraq, "dochadee11979@gmail.com
}

(Received March 27, 2019; Accepted July 20, 2019)

\begin{abstract}
The aim of this study to evaluate the effect of $\beta$-mannanase. Lysolecithin and Probiotic on some reproductive performance and hormone profile in female quail. Six hundred one day - old quail birds were randomly divided to four treatments $(60$ birds/treatment) with 3 replicates for each group treatment ( 20 birds / replicate) and at three duration periods. The first period 1-7 weeks, second period 7 - 13 weeks, third period 1-13 weeks. The group of study were control was fed on a standard ration. the second, third and fourth treatments were given $\beta$-mannanase. Lysolecithin. probiotic $0.5 \mathrm{~g} / \mathrm{kg}$ ration respectively. Blood samples wear taken for blood serum analysis. including estimation of follicle- stimulating hormone and luteinizing hormone. The results revealed that the treated groups showed a significant increase in relative weight of the ovary and oviduct compared with control group. $\beta$-mannanase and probiotic groups showed a significant increase in the oviduct length compared with the control and Lysolecithin groups. There was a significant increase in the numbers of growing and mature follicles and weight of large follicle in all treated groups compared with control group. The $3^{\text {rd }}$ period showed a significant increase in the relative weight of ovary. oviduct and numbers of growing follicles. while the $2^{\text {nd }}$ and $3^{\text {rd }}$ period showed a significant increase in the oviduct length. About the interaction between treatments and periods. the best result appeared in the ovarian relative weight in the $3^{\text {rd }}$ period for probiotic and $\beta$-mannanase. the $3^{\text {rd }}$ period of probiotic showed a significant increase in the oviduct relative weight and for the oviduct length at $2^{\text {ed }}$ and $3^{\text {rd }}$ period for probiotic and $\beta$-mannanase. while $3^{\text {rd }}$ period of probiotic show best interaction in the numbers of growing follicles, as $2^{\text {nd }}$ and $3^{\text {rd }}$ periods showed better increase in the mature follicle's numbers and for large follicle weight in $1^{\text {st }}$ and $2^{\text {nd }}$ period of probiotic. The result also showed a significant increase in the FSH and LH level in all treated groups compared with control group. The $2^{\text {nd }}$ and $3^{\text {rd }}$ period were better significantly in the level of FSH and LH. Probiotic at $2^{\text {nd }}$ and $3^{\text {rd }}$ period showed a significant interaction on the level of FSH. On the other hand, $2^{\text {nd }}$ and $3^{\text {rd }}$ period for the $\beta$-mannanase and probiotic showed a better significant in the LH level. In conclusion. $\beta$-mannanase. Lysolecithin and probiotic supplementation to quail ration improved the hormonal status and enhance reproduction.
\end{abstract}

Keywords: $\beta$-mannanase, Lysolecithin, Probiotic, Quail, Reproduction Available online at http://www.vetmedmosul.com, (C) 2020, College of Veterinary Medicine, University of Mosul. This is an open access article under the CC BY 4.0 license (http://creativecommons.org/licenses/by/4.0/).

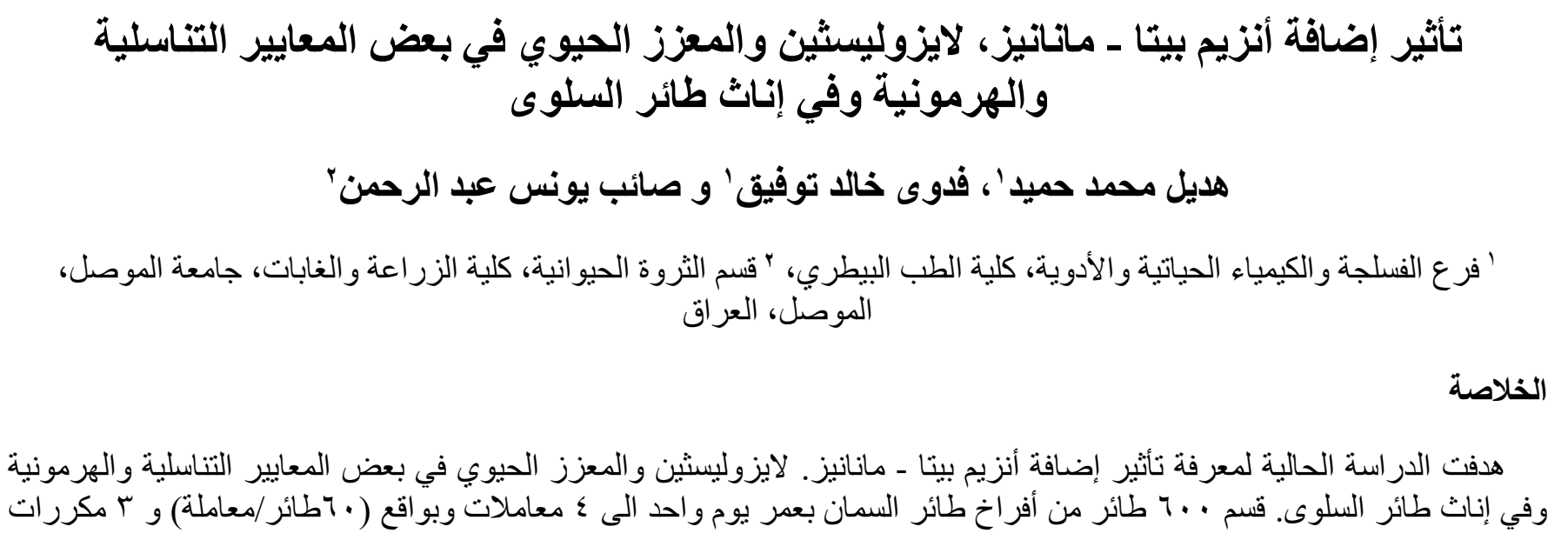




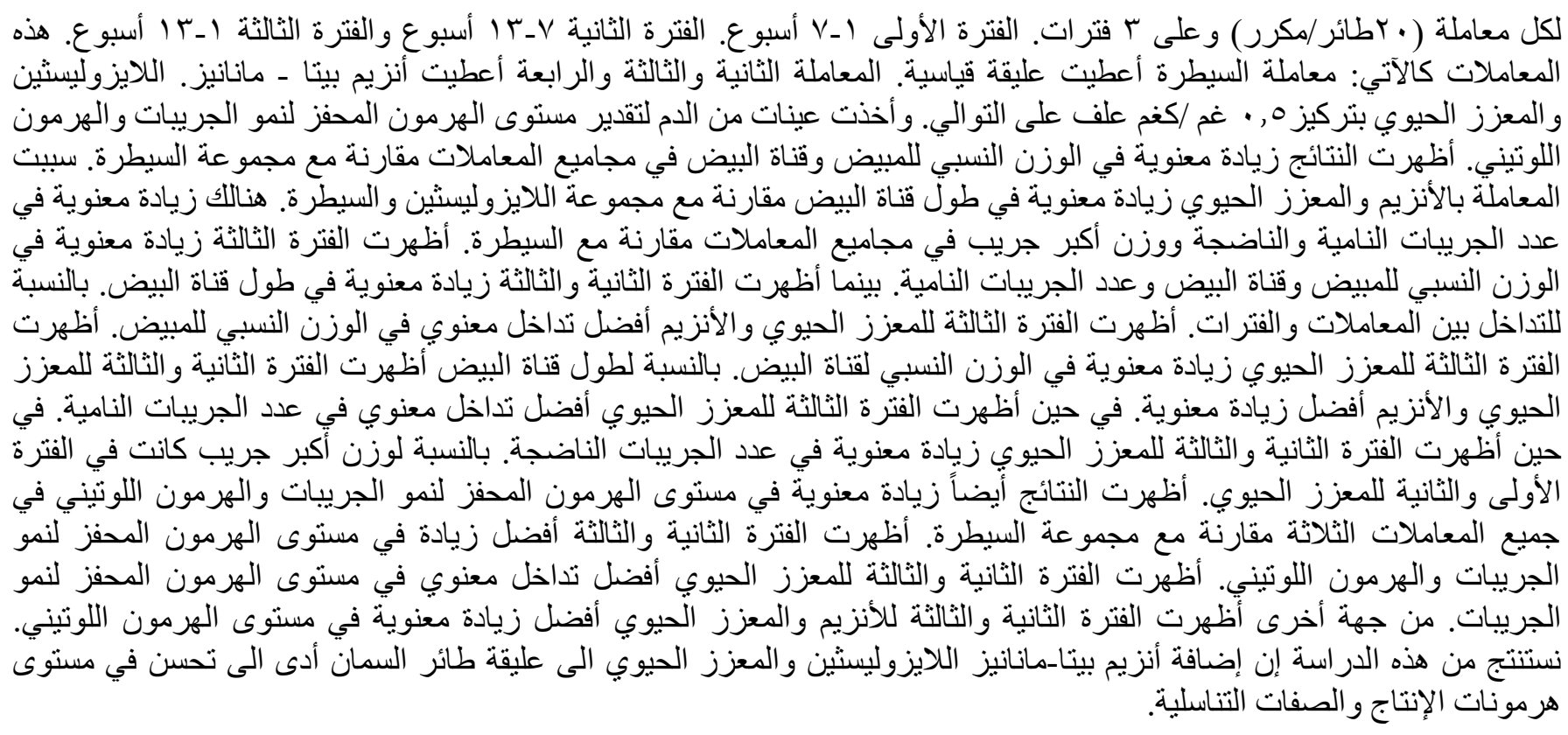

\section{Introduction}

Poultry is an important animal protein source, as it is a cornerstone in filling an important part of humans food needs. The poultry industry has achieved significant progress in recent years. The poultry productivity has increased significantly due to the great progress and large and highly efficient made in applied research in various fields of this industry (1). Therefore, the recent studies are trying to focus in all scientific fields to yield animals that have high production specifications with lowest costs taking into account the shortest time period of production. As a result of the increasing demand for animal protein, especially poultry, studies have focused on rearing quail, which is resistant to disease, small-scale, dual-purpose, low-cost in breeding. As well as characterized by rapid sexual maturity, shortening the period of other generation formation, it is characterized by a very rapid growth rate and high meat and eggs production. female puts between 250 - 300 eggs per year as well as breeding in accordance with an intensive breeding system with a number of 80-100 birds $/ \mathrm{m}^{2}$ (2). Feed additives are of the most important strategy in order to improve the productivity of poultry industry as organic acids and macrominerals (3), as well as $\beta$-mannanase to enhance benefit of ration, which has become common during the previous ten years (4). In addition, they treat the negative impact of low-energy bonds (5). One of these are $\beta$-mannanase (6). Ibuki et al (7) indicated that the addition of $\beta$-mannanase to poultry rations led to regular body weight and improved dietary conversion ratio. Other additives that have been used are emulsions. Recent studies have indicated that the use of these emulsifiers as feed additives can support bile salts in fat emulsification process and micelles formation. Thus, showing a positive effect in the process of fats digestion (8). Where the studies conducted on humans and animals proved the ability of probiotics to change the type and number of intestinal microflora (9). The probiotic plays an important role in the natural gastrointestinal processes of the gastrointestinal tract of poultry, thus preserving the health of the animal, the disease also causes changes in the physico-chemical environment of the digestive tract also any slight change in the quality of food can significantly affect the microbial assembly thus affecting the health of the bird (10).

The aim of this study was to investigate the effect of $\beta$ mannanase, lysolecithin and probiotic on some reproductive parameters and hormonal status of female quail breeders.

\section{Materials and methods}

Field experiments and laboratory analysis were carried out at the animal house and laboratories of Veterinary Medicine, University of Mosul. In this study, the quail birds were obtained by hatching fertilized eggs from the Agriculture and Forestry College, University of Mosul. The birds were raised from $1^{\text {st }}$ day of its ages to the end of the study period was 13 weeks in a closed-type hall. the ground floor of the hall divided into ten rooms with dimensions $1.5 \times 2.5 \mathrm{~m}$, each room was divided into three separate rooms each room have a door and fully covered with soft metal wire, equipped with feed bowl, plastic water bowel, evacuator and thermometers, sawdust was used $5 \mathrm{~cm}$ in thickness as a ground floor. The birds were fed on two 
types rations the starter and finisher. The starter ration gave from $1^{\text {st }}$ day to 3 weeks age and the finisher gaved until the end of the experiment at 13 weeks age by using special plastics bowels for water and ration ad libitum, according to the decisions of the US National Research Council (11) (Table 1). The study was conducted on 600 quail birds (one week old) were randomly distributed in to ten groups (60 birds / group). The animals were divided in to three replicates (20 birds / replicate), the experimental groups treated as follows: the first group as control was given standard ration without addition. The second group was given a standard ration containing $\beta$-mannanase with a concentration of $0.5 \mathrm{~g} / \mathrm{kg}$ ration. The third group was given a standard ration containing lysolecithin with a concentration of $0.5 \mathrm{~g} / \mathrm{kg}$ ration. The fourth group was given a ration with a probiotic with a concentration of 0.5 $\mathrm{g} / \mathrm{kg}$ ration. The study was divided into three periods, first period at age 1-7 weeks. The second period at age 7-13 weeks and the third period at age 1-13 weeks. The birds were separated depending on gender by relying on what called a cloacal gland this gland only founded in males as a swelling reach $1-1.5 \mathrm{~cm}$ in the upper side of the cloaca which is getting bigger at the sexual growing age with pressing this gland a soap like foam material comes out so it's also called a Foam gland.

Table 1: Composition of starter and finisher ration

\begin{tabular}{lcc}
\hline Ingredients & $\begin{array}{c}\text { Growth } \\
\text { ration \% }\end{array}$ & $\begin{array}{c}\text { Production } \\
\text { ration \% }\end{array}$ \\
\hline Maize & 36 & 42 \\
Wheat & 22 & 22 \\
Soy bean meal (24\% protein) & 35 & 30 \\
Premix (40\%protein) & 5 & 4 \\
Vegetable oil & 1 & 1 \\
Limestone & 0.7 & 0.7 \\
Salt & 0.3 & 0.3 \\
Total & 100 & 100 \\
\hline Calculated Values* & & \\
\hline Metabolizable energy (Kal/kg) & 2821.8 & 2985.1 \\
Crude protein \% & 24.270 & 21.998 \\
Crude fiber \% & 3.975 & 3.650 \\
\hline
\end{tabular}

* According to N.R.C.1994

\section{Collection of blood samples}

Blood samples were collected at the end of each period of the treatments by cervical dislocation of each bird (6 bird/ treatment) from each group. Serum samples were taken and stored under $-20{ }^{\circ} \mathrm{C}$ until assayed serum of follicle stimulating hormone (FSH) and luteinizing hormone (LH), were measured by using $\beta$-mannanase immunoassay test kit based on quantitative test of a solid phase B-mannanase - Linked immunosorbent Assay (ELISA).

\section{Relative organs weight}

After slaughtered the bird relative weight of ovary, oviduct, length of oviduct, numbers of growing, mature follicles, weight of large follicle was recorded, weighted, calculated as a percentage of life body weight.

\section{Statistical analysis}

In this study a complete randomized design CRD and twoway analysis of variance and the difference between groups determined by Duncan's multiple range test (12) by using the ready statistical program SAS (13) under the level of significance $\mathrm{P} \leq 0.05$.

\section{Results}

Data presented in table 2 and consequent table 2 showed the effect of $\beta$-mannanase, lysolecithin and probiotic on relative weight of ovary, oviduct, length of oviduct, numbers of growing and mature follicles and weight of large follicle. Statistical analysis showed a significant increase in the relative weight of ovary and oviduct in $\beta$ mannanase, lysolecithin and probiotic compared with the control group, the $\beta$-mannanase and probiotic were superior than lysolecithin group. The result showed a significant increase in the oviduct length in $\beta$-mannanase and probiotic groups compared with lysolecithin and control groups. The result also showed a significant increase in the numbers of growing and mature follicles and weight of large follicle in the treatment groups compared with the control group. Whereas the probiotic group superior than lysolecithin and $\beta$-mannanase in the numbers of growing and mature follicles and weight of the large follicle. The $3^{\text {rd }}$ period of probiotic showed a significant increase in the relative weight of ovary. Oviduct and numbers of growing follicles, while the $2^{\text {nd }}$ and $3^{\text {rd }}$ period showed a significant increase in the length of oviduct. About the interaction between the treatments and periods, the best result in the relative weight of ovary in $3^{\text {rd }}$ period for probiotic and $\beta$-mannanase and in the $3^{\text {rd }}$ period for probiotic group in relative weight of oviduct and for the length of oviduct in the $2^{\text {nd }}$ and $3^{\text {rd }}$ period for probiotic and $\beta$-mannanase. While the $3^{\text {rd }}$ period of probiotic show best interaction in the numbers of growing follicles, as in the $2^{\text {nd }}$ and $3^{\text {rd }}$ of probiotic in the numbers of mature follicles and for the weight of large follicle in the $1^{\text {st }}$ and $2^{\text {nd }}$ period of probiotic.

Figure 1 and 2 indicate the effect of $\beta$-mannanase, lysolecithin and probiotic on the level FSH and LH. The result shows a significant increase in FSH and LH level in all treated groups compared with control group. Also, the $\beta$ mannanase and probiotic superior the lysolecithin group. About the period (Figures 3 and 4 ) the $2^{\text {nd }}$ and $3^{\text {rd }}$ period was better significantly in the level of FSH and LH. For the interaction between the treatment and period (Figures 5 and 6 ) probiotic group at $2^{\text {nd }}$ and $3^{\text {rd }}$ period showed a significant 
increase in FSH level. On the other hand, $2^{\text {nd }}$ and $3^{\text {rd }}$ period for $\beta$-mannanase and probiotic showed a significant increase on the LH level compared with other groups.

Table 2: Effect of $\beta$-mannanase. Lysolecithin and probiotic on some reproductive parameters in female quail

\begin{tabular}{|c|c|c|c|c|c|c|c|}
\hline \multirow[b]{2}{*}{ 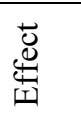 } & \multirow[b]{2}{*}{ Groups } & \multicolumn{6}{|c|}{ Parameters Means \pm SE $(n=6)$} \\
\hline & & $\begin{array}{c}\text { ovary \% } \\
\text { relative weight }\end{array}$ & $\begin{array}{l}\text { oviduct \% } \\
\text { relative weight }\end{array}$ & $\begin{array}{c}\text { oviduct } \\
\text { length }(\mathrm{cm})\end{array}$ & $\begin{array}{l}\text { no of growing } \\
\text { follicles }\end{array}$ & $\begin{array}{l}\text { no of mature } \\
\text { follicles }\end{array}$ & $\begin{array}{c}\text { large follicle } \\
\text { weight }(\mathrm{g})\end{array}$ \\
\hline \multirow{4}{*}{ 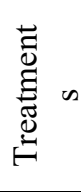 } & Control & $3.44 \pm 0.04^{\mathrm{c}}$ & $3.36 \pm 0.01^{\mathrm{c}}$ & $40.53 \pm 0.14^{b}$ & $23.22 \pm 0.26^{\mathrm{c}}$ & $3.27 \pm 0.15^{\mathrm{c}}$ & $2.83 \pm 0.07^{\mathrm{c}}$ \\
\hline & $\beta$-mannanase & $4.42 \pm 0.03^{\mathrm{a}}$ & $4.41 \pm 0.03^{\mathrm{a}}$ & $41.19 \pm 0.10^{\mathrm{a}}$ & $30.27 \pm 0.46^{\mathrm{b}}$ & $4.72 \pm 0.13^{b}$ & $3.58 \pm 0.05^{b}$ \\
\hline & Lysolecithin & $4.05 \pm 0.04^{b}$ & $4.10 \pm 0.05^{b}$ & $40.82 \pm 0.12^{b}$ & $29.77 \pm 0.17^{b}$ & $4.44 \pm 0.12^{b}$ & $3.49 \pm 0.07^{\mathrm{b}}$ \\
\hline & Probiotic & $4.39 \pm 0.03^{\mathrm{a}}$ & $4.39 \pm 0.03^{\mathrm{a}}$ & $41.17 \pm 0.11^{\mathrm{a}}$ & $32.11 \pm 0.27^{\mathrm{a}}$ & $5.27 \pm 0.13^{\mathrm{a}}$ & $3.90 \pm 0.02^{\mathrm{a}}$ \\
\hline \multirow{3}{*}{$\begin{array}{l}\frac{n}{0} \\
0 \\
0 \\
0\end{array}$} & $1^{\text {st }}$ period & $4.05 \pm 0.06^{b}$ & $4.02 \pm 0.08^{b}$ & $40.64 \pm 0.10^{b}$ & $28.37 \pm 0.66^{b}$ & $4.41 \pm 0.23^{\mathrm{a}}$ & $3.46 \pm 0.11^{\mathrm{a}}$ \\
\hline & $2^{\text {nd }}$ period & $4.01 \pm 0.08^{b}$ & $4.01 \pm 0.08^{b}$ & $41.10 \pm 0.12^{\mathrm{a}}$ & $28.54 \pm 0.70^{\mathrm{b}}$ & $4.41 \pm 0.16^{\mathrm{a}}$ & $3.470 .08^{\mathrm{a}}$ \\
\hline & $3^{\text {rd }}$ period & $4.17 \pm 0.1^{\mathrm{a}}$ & $4.16 \pm 0.10^{\mathrm{a}}$ & $41.04 \pm 0.10^{\mathrm{a}}$ & $29.62 \pm 0.83^{\mathrm{a}}$ & $4.45 \pm 0.17^{\mathrm{a}}$ & $3.41 \pm 0.08^{\mathrm{a}}$ \\
\hline
\end{tabular}

Different letters within columns indicate significant differences at $\mathrm{P} \leq 0.05$.

Consequent table 2: Effect of $\beta$-mannanase. Lysolecithin and Probiotic on some reproductive parameters in female quail

\begin{tabular}{lcccccc}
\hline \multirow{2}{*}{ Groups } & \multicolumn{5}{c}{ Parameters, Means $\pm \mathrm{SE}$ (n=6) Effect of interaction between treatments and periods } \\
\cline { 2 - 7 } & $\begin{array}{c}\text { ovary \% } \\
\text { relative weight }\end{array}$ & $\begin{array}{c}\text { oviduct \% } \\
\text { relative weight }\end{array}$ & $\begin{array}{c}\text { oviduct length } \\
(\mathrm{cm})\end{array}$ & $\begin{array}{c}\text { no of growing } \\
\text { follicles }\end{array}$ & $\begin{array}{c}\text { no of mature } \\
\text { follicles }\end{array}$ & $\begin{array}{c}\text { large follicle } \\
\text { weight }(\mathrm{g})\end{array}$ \\
\hline Control P1 & $3.65 \pm 0.09 \mathrm{~d}$ & $3.39 \pm 0.04 \mathrm{f}$ & $40.14 \pm 0.21 \mathrm{c}$ & $23.33 \pm 0.61 \mathrm{e}$ & $2.83 \pm 0.30 \mathrm{~d}$ & $2.62 \pm 0.05 \mathrm{f}$ \\
Control P2 & $3.34 \pm 0.02 \mathrm{e}$ & $3.34 \pm 0.02 \mathrm{f}$ & $40.73 \pm 0.24 \mathrm{abc}$ & $23.16 \pm 0.40 \mathrm{e}$ & $3.50 \pm 0.22 \mathrm{~d}$ & $2.93 \pm 0.15 \mathrm{e}$ \\
Control P3 & $3.340 .02 \mathrm{e}$ & $3.34 \pm 0.02 \mathrm{f}$ & $40.73 \pm 0.24 \mathrm{abc}$ & $23.16 \pm 0.40 \mathrm{e}$ & $3.50 \pm 0.22 \mathrm{~d}$ & $2.93 \pm 0.15 \mathrm{e}$ \\
$\beta$-mannanase P1 & $4.37 \pm 0.10 \mathrm{~b}$ & $4.35 \pm 0.07 \mathrm{c}$ & $40.97 \pm 0.13 \mathrm{ab}$ & $29.50 \pm 0.76 \mathrm{~d}$ & $5.00 \pm 0.25 \mathrm{abc}$ & $3.75 \pm 0.08 \mathrm{abc}$ \\
$\beta$-mannanase P2 & $4.38 \pm 0.03 \mathrm{~b}$ & $4.37 \pm 0.03 \mathrm{bc}$ & $41.33 \pm 0.19 \mathrm{a}$ & $29.66 \pm 0.71 \mathrm{~d}$ & $4.50 \pm 0.22 \mathrm{bc}$ & $3.53 \pm 0.04 \mathrm{~cd}$ \\
$\beta$-mannanase P3 & $4.53 \pm 0.02 \mathrm{a}$ & $4.52 \pm 0.01 \mathrm{ab}$ & $41.27 \pm 0.18 \mathrm{a}$ & $31.66 \pm 0.71 \mathrm{bc}$ & $4.66 \pm 0.21 \mathrm{abc}$ & $3.45 \pm 0.10 \mathrm{~cd}$ \\
Lysolecithin P1 & $3.94 \pm 0.07 \mathrm{c}$ & $4.09 \pm 0.14 \mathrm{de}$ & $40.51 \pm 0.16 \mathrm{bc}$ & $29.50 \pm 0.22 \mathrm{~d}$ & $4.66 \pm 0.21 \mathrm{abc}$ & $3.58 \pm 0.15 \mathrm{bcd}$ \\
Lysolecithin P2 & $3.97 \pm 0.03 \mathrm{c}$ & $3.97 \pm 0.03 \mathrm{e}$ & $41.07 \pm 0.23 \mathrm{ab}$ & $29.50 \pm 0.22 \mathrm{~d}$ & $4.33 \pm 0.21 \mathrm{c}$ & $3.53 \pm 0.11 \mathrm{~cd}$ \\
Lysolecithin P3 & $4.24 \pm 0.01 \mathrm{~b}$ & $4.24 \pm 0.00 \mathrm{~cd}$ & $40.88 \pm 0.20 \mathrm{ab}$ & $30.33 \pm 0.33 \mathrm{~cd}$ & $4.33 \pm 0.21 \mathrm{c}$ & $3.36 \pm 0.11 \mathrm{~d}$ \\
Probiotic P1 & $4.25 \pm 0.02 \mathrm{~b}$ & $4.25 \pm 0.02 \mathrm{~cd}$ & $40.95 \pm 0.17 \mathrm{~b}$ & $31.16 \pm 0.30 \mathrm{bc}$ & $5.16 \pm 0.30 \mathrm{ab}$ & $3.91 \pm 0.02 \mathrm{a}$ \\
Probiotic P2 & $4.36 \pm 0.03 \mathrm{~b}$ & $4.37 \pm 0.03 \mathrm{bc}$ & $41.27 \pm 0.25 \mathrm{a}$ & $31.83 \pm 0.30 \mathrm{~b}$ & $5.33 \pm 0.21 \mathrm{a}$ & $3.90 \pm 0.05 \mathrm{a}$ \\
Probiotic P3 & $4.56 \pm 0.01 \mathrm{a}$ & $4.56 \pm 0.01 \mathrm{a}$ & $41.28 \pm 0.18 \mathrm{a}$ & $33.33 \pm 0.33 \mathrm{a}$ & $5.33 \pm 0.21 \mathrm{a}$ & $3.88 \pm 0.04 \mathrm{ab}$ \\
\hline
\end{tabular}

Different letters within columns indicate significant differences at $\mathrm{P} \leq 0.05, \mathrm{P} 1=$ first period $\mathrm{p} 2=$ second period $\mathrm{p} 3=$ third period.

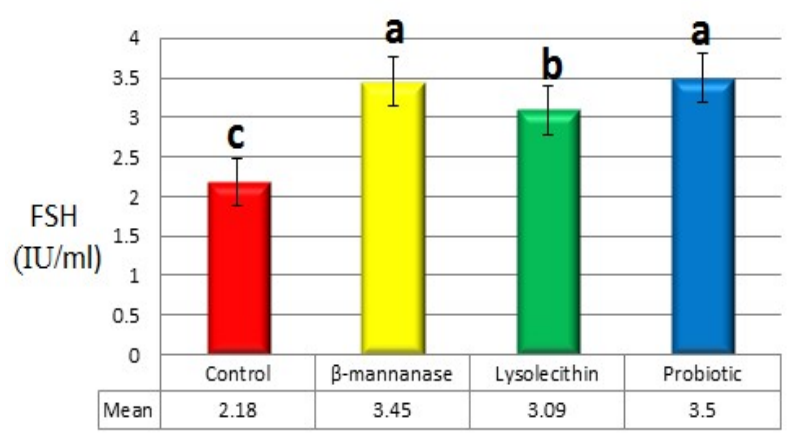

Figure 1: Effect of $\beta$-mannanase, lysolecithin and probiotic on FSH level in serum of quail breeders (effect of treatment).

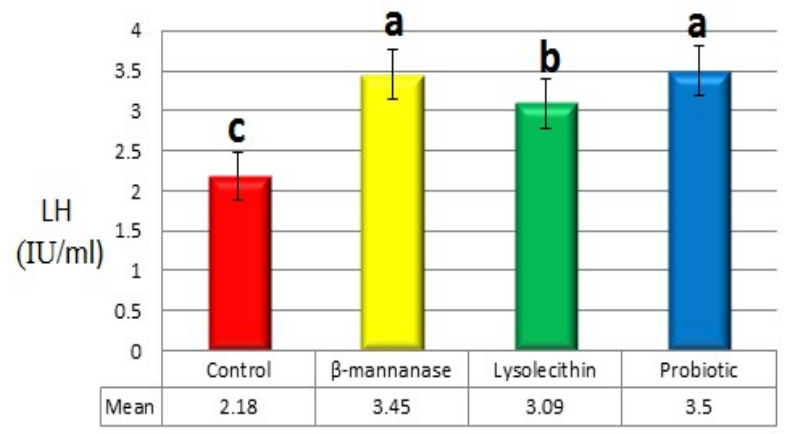

Figure 2: Effect of $\beta$-mannanase, lysolecithin and probiotic on LH level in serum of quail breeders (effect of treatment). 


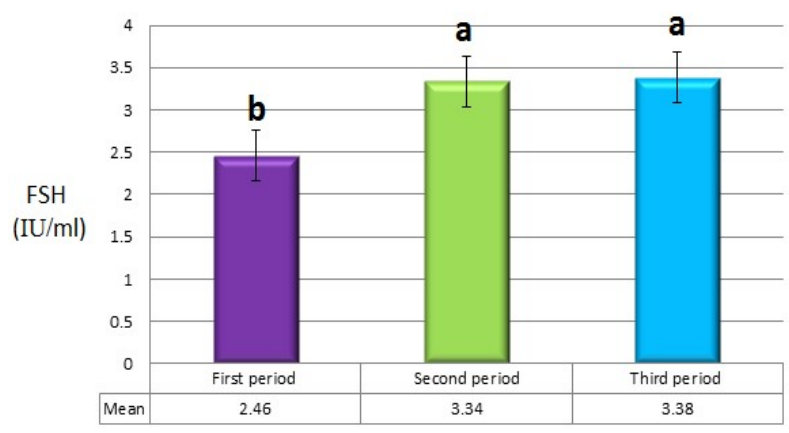

Figure 3: Effect of $\beta$-mannanase, lysolecithin and probiotic on FSH level in serum of quail breeders (effect of periods).

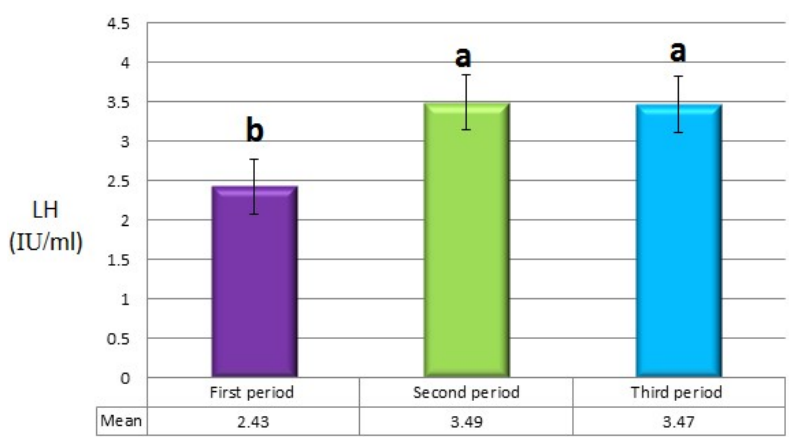

Figure 4: Effect of $\beta$-mannanase, lysolecithin and probiotic on LH level in serum of quail breeders ( effect of periods).

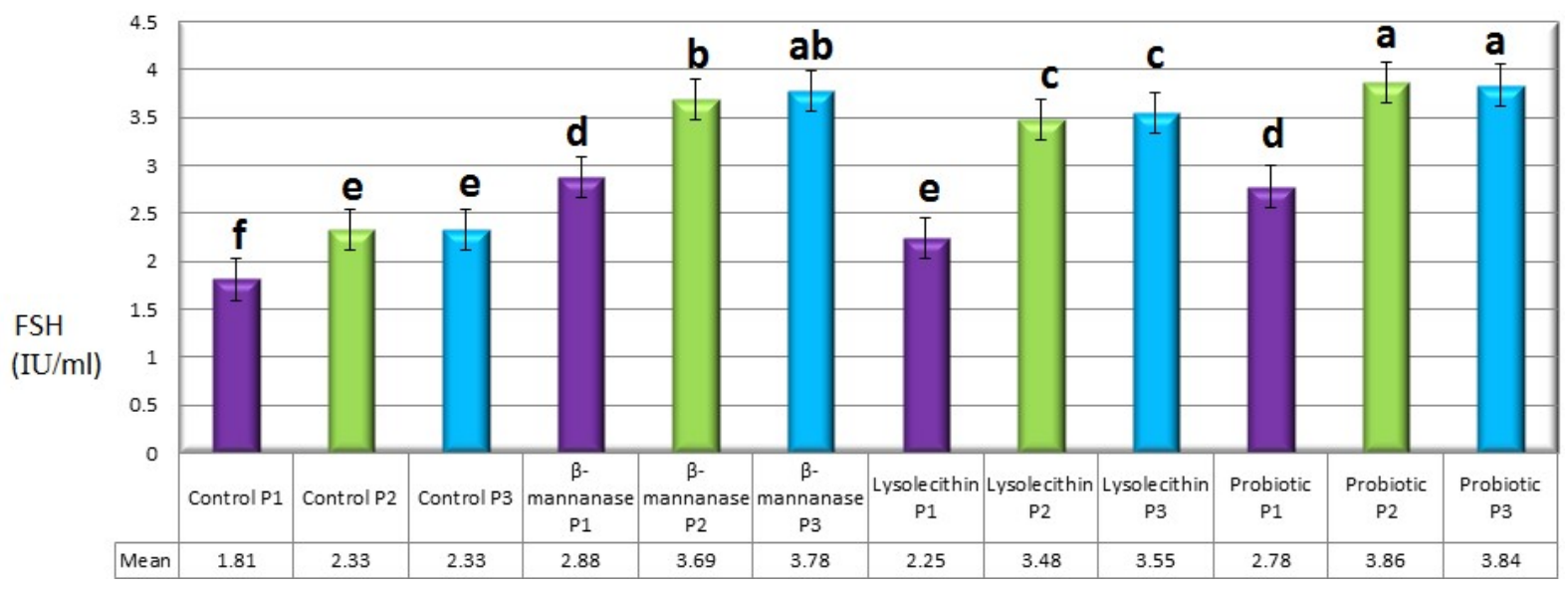

Figure 5: Effect of $\beta$-mannanase, lysolecithin and probiotic on FSH level in serum of quail breeders (effect of interaction between treatment and periods) $\mathrm{P} 1=$ first period $\mathrm{P} 2=$ second period $\mathrm{P} 3=$ third period.

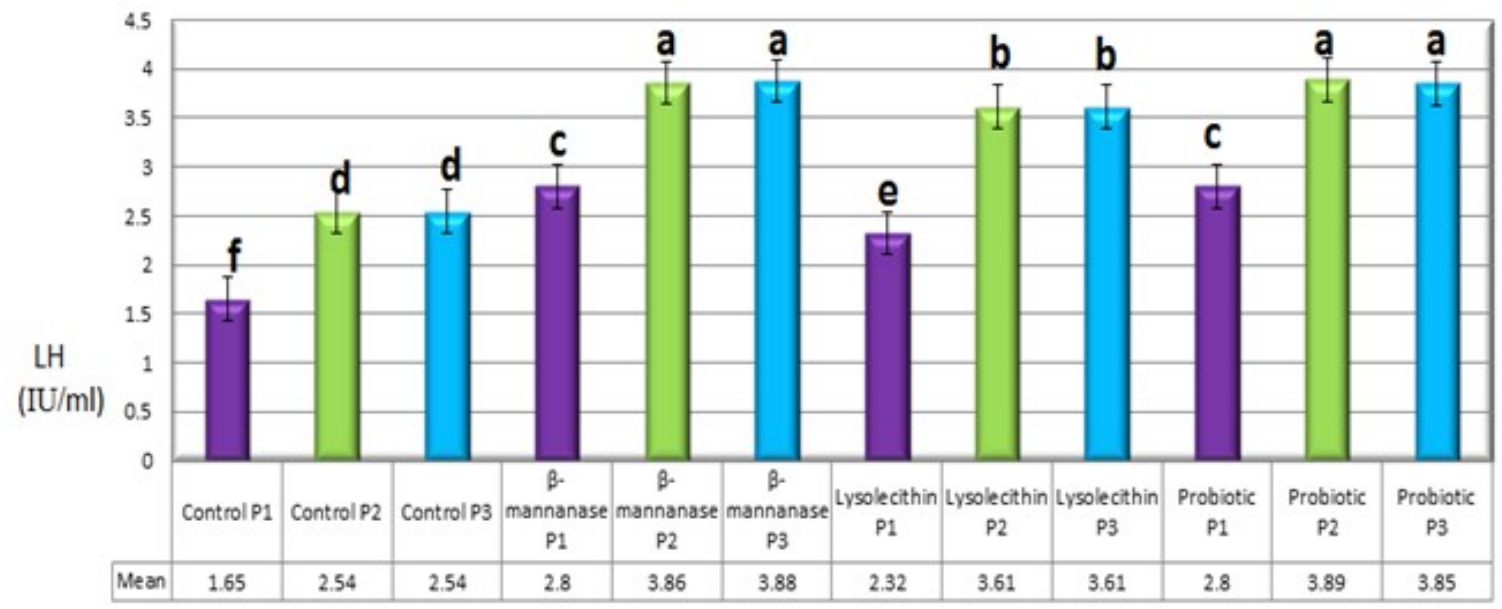

Figure 6: Effect of $\beta$-mannanase, lysolecithin and probiotic on LH level in serum of quail breeders (effect of interaction between treatment and periods) $\mathrm{P} 1=$ first period $\mathrm{P} 2=$ second period $\mathrm{P} 3=$ third period. 


\section{Discussion}

The result showed a significant increase in some reproductive parameters such as relative weight of ovary, oviduct, numbers of growing and mature follicles, weight of large follicle. From the result it could be postulate that this improvement in these parameters may be due to the hormonal status improvement specially the FSH level which enhance the follicles growing and the balance with LH level which enhance the ovulation rate, this suggestion was sustained by a significant increase in FSH and LH levels in the current study. This was agreed with Sultan and Abdul-Rhaman (14) who reported that probiotic at 10, 20 $\mathrm{g} / \mathrm{kg}$ ration to broiler lead to increase level of FSH and LH. Improvement in FSH and $\mathrm{LH}$ levels were reflected an increase in the egg yolk weight by FSH and improvement of egg production\% by LH (14), also this increase in FSH and LH level reflected by via improvement in animal performance, $\beta$-mannanase increase protein and minerals assimilation by reduce digestive viscosity and enhance the activity of digestive in the intestine $\mathrm{Lv}$ et al (15). $\beta$ mannanase decrease the viscosity of digesta, increase the rate of diffusion involved in the digestion and absorption of nutrient in the small intestine Jackson et al (16). The important role of $\beta$-mannanase is hydrolyzing $\beta-1,4$ glycosidic linkages in mannan (anti-nutrient compound) to produce mannan-oligosaccharide (MOS) Khanongnuch et al (17). MOS supplementation at $1 \mathrm{~kg} / \mathrm{ton}$ lead to improvement in egg production in quail, it has been supposed that the benefits of MOS based on its specific properties such as modification of the intestinal flora, reduction in turnover rate of the intestinal mucosa and modulation of immune system (18). The improvement in the weight of the female reproductive system may be due to improved nutritional status of the bird, where Gao et al (19) noted that changes in regulating the metabolism and function of organs that are dependent on the growth of the endocrine system have an important relationship to changes in the nutritional state of the bird so the use of external enzymes is an effective way to break down the walls of the cells of anti-nutrient compounds and improve the efficiency of production for non-ruminants including poultry. The importance of external emulsions is to improve digestion by increasing the formation of emulsified droplets that reduce surface tension and stimulate the formation of lipid particles and increase the concentration of monounsaturated fats in the intestines and thus facilitate the transfer of digested food through the walls of the intestines and facilitate the absorption process and power processing $(20,21)$ and this will improved fat and protein digestion (22). Probiotic in poultry have several actions include maintaining normal intestinal microflora by competitive exclusion antagonism, competing for mucosal attachment, lowering the $\mathrm{pH}$ through acid fermentation, stimulating the immune system associated with the gut, producing bacteriocins and increasing production of short- chain fatty acids Chiara et al (23). The most characteristics of the probiotic are to compete with pathogenic bacteria on the adhesion site of the target organ, these site are usually in the gastrointestinal tract and the female reproductive canal and its adhesion ability is due to adhesion factors on the surface of the probiotic and existing receptors in host cells and especially epithelial cells in the intestine (24).

\section{Conclusion}

We concluded from this study that $\beta$-mannanase, lysolecithin and probiotic supplementation to quail ration showed a significant improvement on some reproduction parameters and hormonal status. Therefore. these products might be promising alternative for antibiotic growth promoters in animal feed.

\section{Acknowledgments}

The authors acknowledge the College of Veterinary Medicine for providing facilities and financial support to this study.

\section{Reference}

1. Ranco M, Giovani C, Claudio C, Nicola F, Andrea G, Lucio L, Andrea $\mathrm{P}$. Role of poultry meat in a diet aimed at maintaining health and wellbeing: an Italian consensus document. Food Nutr Res. 2015;59:10. doi:10:3402/fnr.v59.22760

2. Sertac A. Genetic researches on growth traits of Japanese quail. AIP Conference Proceeding. 2017;1833:1. doi.org/10.1063/1.4981720

3. Swiatkiewicz S, Arczewska A. Prebiotic fructus and organic acid as feed additives improving mineral availability. Poult Sci J. 2012;68. doi.10.1017/s0043933912000323

4. DeBarros VRS, Lana GRQ, Lana SRV, Cunha FS, Neto JV. $\beta$ mannanase and mono-oligosaccharides in broiler chicken feed. Cie Rur. 2015;45:111-117. doi.10.1590/0103-8478cr20131544

5. Graham KK, Kerley JD, Firman GL. The effect of enzyme treatment of soy bean on oligosaccharide disappearance and chick growth performance. Poult Sci Feed. 2002;81:1014-1019. doi/10.1094/ps/81.7.1014

6. Wu GMM, Bryant RA, Viotle DA. Effect of beta-mannanase in corn soy rations on commercial leghorns in second - cycle hens. Poult Sci. 2005;84:894-897. doi.org/10.1093/ps/84.894

7. Ibuk M, Yoshimoto Y, Yamasaki H, Handa K. Effect of rationay $\beta$ 1.4-mannobiose on the growth of growing broiler chicks. J Poult Sci. 2013;50:120-125. doi.org/10.2141/ps9012138

8. Joshi A, Paratkar SG, Thorat BN. Modification of lecithin by physical, chemical and enzymatic methods. Eur J Lipid Sci Technol. 2006;108:363-373. doi.org/10.1002/ejlt.200600016

9. Saulnier DM. Identification of prebiotic fructo-oligosaccharide metabolism in Lactobacillus plantarum WCFS1 through microarrays. Appl Environ Microbiol. 2007;73:1753. doi.org/10.1128/aem.0115-06

10. Tannok GW, Jeremy H. Probiotic and prebiotic: Scientific aspects. J Antimicrob Chem. 2006;58(1):232-233. doi.org/10.1093/jac/dk171

11. National Research Council (NRC). Nutrient requirement of poultry. $9^{\text {th }} \quad$ ed. Washington: National Academy press; 1994. doi.org/10.1093/japr/3.1101 
12. Duncan DB. Multiple range and multiple $F$ teste. Biometrics. 1983;11:1-42. doi.org/10.2307/3001478

13. SAS. SAS/STAT. User's Guide for Personal Computers Institute. USA: Cary Inc; 2010. doi.org/10.1007/s00362-008-0156-x

14. Sultan KH, Abdul-Rahman SY. Effect of probiotic on some physiological parameters in broiler breeder. Inter $\mathrm{J}$ Poult Sci. 2011;10(8):626-628. doi.org/10.3923/ijps.2011.626.628

15. Lv JN, Chen YQ, Guo XJ, Piao S, Cao YH, Don B. Effect of supplementation of beta-mannanase in corn-soybean meal ration on performance and nutrient digestibility in growing pige. Asian Austral J Anim Sci. 2013;26:579-587. doi.org/10.5713.ajas/2012.12612

16. Jackson ME, Geronian K, Knot A, Mcnab J, Mccartney E. A dose response study with the feed enzyme beta-mannanase in broiler provided with corn-soy bean meal based diets in the absence of antibiotic growth promoters. Poult Sci. 2004; 83:1992 -1996. doi.org/10.1093/ps/83.12.1992

17. Khanongnuch $C$, Sanguansook $C$, Lumyong S. Nutritive quality of $\beta$ mannanase treated copra meat in broiler diets and effectiveness on some fecal bacteria. Int $J$ Poult Sci. 2006;5(11):1087-1091. doi.org/10.3923/jps.2006.1087-1091

18. Berrin KG. Effect of probiotic and prebiotic (mannan-oligosaccharide) supplementation on performance, egg quality and hatchability in quail breeds. Ankara Univ Vet Fak Derg. 2011;58:27-32. doi.org/10.1501/vetfak0000002445
19. Gao F, Jang Y, Zhon GH, Han ZK. The effects of xylanase supplementation on performance, characteristics of the gastrointestinal tract, blood parameter and gut microflora in broilers fed on wheatbased diets. Anim Feed Sci Technol. 2007;142:173-184. doi.org/10.1016.j.anifeed Sci.2007.07.008

20. Han YK, Jin YH, Lee WI, Lee KT, Thacker PA. Influence of lysolecithin on the performance of laying hens interior and exterior egg quality as well as fat soluble vitamin and cholesterol content in the yolk. J Anim Vet Sci. 2010;9(20):2583-2588. doi.org/10.3923/java.2010.2583.2588

21. Roy A, Haldar S, Mondal S, Ghosh K. Effect of supplemental exogenous emulsifier on performance, nutrient metabolism and serum lipid profile in broiler chickens. Vet Med Inter. 2010;10:1-9. doi.org/10.4061/2010/262604

22. Xing JJ, Vanheugten E, Li DF, Touchtte KJ, Coalson JA, Odgaad RL, Odle J. Effect of emulsification, fat encapsulation and pelleting on weanling pig performance and nutrient digestibility. J Anim Sci. 2004;82:2601-2609. doi.org/10.2527/2004.8292601x

23. Chiara D, Marcella R, Erica C. Microbiome and probiotics in health and HIV infection. J Refree Nutr. 2017;9:615. doi:10.3390/nu9060615

24. Saxelin M, Soile T, Tina M, Sand S, Willem MD. Probiotic and other functional microbes: from markets to mechanism. Curr Opin Bacteriol. 2005;16:204-211. doi.org/10.1016/j.copbio.2005.02.003 